\title{
Jurist-Diction
}

Volume 3 No. 6, November 2020

\section{Pertanggungjawaban Negara Dalam Penyelesaian Kasus Pelanggaran Hak Asasi Manusia yang Berat Di Aceh Melalui Mekanisme Komisi Kebenaran dan Rekonsiliasi Aceh}

\author{
Lukman Dwi Hadi Putra Sriwidodo \\ lukman.dwi-12@fh.unair.ac.id \\ Universitas Airlangga
}

How to cite:

Lukman Dwi Hadi

Putra Sriwidodo

'Pertanggungjawaban Negara

Dalam Penyelesaian Kasus

Pelanggaran Hak Asasi

Manusia yang Berat Di Aceh

Melalui Mekanisme Komisi

Kebenaran dan Rekonsiliasi

Aceh' (2020) Vol. 3 No. 6

November Jurist-Diction.

Histori artikel:

Submit 09 Agustus 2020;

Diterima 28 September 2020;

Diterbitkan 1 November 2020 .

DOI:

10.20473/jd.v3i6.22971

\begin{abstract}
Abstrak
Upaya untuk mengungkap pelanggaran Hak Asasi Manusia yang berat telah lama dilakukan dengan adanya mekanisme non-yudisial yaitu Komisi Kebenaran dan Rekonsiliasi (Undang-Undang Nomor 27 Tahun 2004 tentang Komisi Kebenaran dan Rekonsiliasi). Ini membuka jalan bagi pengungkapan kebenaran. Proses ini sangat penting dilakukan untuk meminimalisir konflik warisan yang dapat menjadi penghalang bagi masa depan bangsa. Pemerintah memiliki kewajiban untuk melindungi, menjunjung tinggi dan memajukan Hak Asasi Manusia bagi warga negara. Belajar dari penelitian ini, negara memiliki undang-undang terkait untuk kebenaran dan rekonsiliasi, terutama dalam menyelesaikan pelanggaran Hak Asasi Manusia masa lalu. Namun, undang-undang yang awalnya menjadi dasar hukum untuk mengungkapkan kebenaran telah dicabut oleh Mahkamah Konstitusi. Karenanya, tidak ada lagi dasar hukum untuk kebenaran dan rekonsiliasi di Indonesia. Namun, Komisi Kebenaran dan Rekonsiliasi Aceh telah dibentuk berdasarkan Nota Kesepahaman antara Pemerintah Republik Indonesia dan Gerakan Aceh Merdeka, di Helsinki, Finlandia pada 15 Agustus 2005 (MoU Helsinki). MoU ini telah diadaptasi menjadi Undang-Undang Nomor 11 Tahun 2006 tentang Pemerintahan Aceh dan Qanun Aceh Nomor 17 Tahun 2013. Artikel ini berfokus pada dua pertanyaan, apa posisi hukum dan wewenang Komisi Kebenaran dan Rekonsiliasi Aceh dalam sistem hukum Indonesia dalam menjamin dan melindungi hak-hak para korban pelanggaran Hak Asasi Manusia yang berat dalam kasus-kasus di Aceh, dan apakah mekanisme perlindungan dan pertanggungjawaban Negara dalam memberikan langkah-langkah hukum dapat memenuhi hak-hak para korban pelanggaran Hak Asasi Manusia yang berat di Aceh.

Kata Kunci: Pelanggaran Hak Asasi Manusia; Tanggung Jawab Negara; Komisi Kebenaran dan Rekonsiliasi Aceh.
\end{abstract}

\section{Pendahuluan}

Pelanggaran Hak Asasi Manusia diartikan sebagai setiap perbuatan seseorang atau kelompok orang termasuk aparat negara, baik disengaja, atau kelalaian yang secara melawan hukum mengurangi, menghalangi, membatasi dan atau mencabut 
Hak Asasi Manusia seseorang atau kelompok orang yang dijamin oleh undangundang ini, dan tidak mendapatkan, atau dikhawatirkan tidak akan memperoleh penyelesaian hukum yang adil dan benar, berdasarkan mekanisme hukum yang berlaku. Pelanggaran Hak Asasi Manusia (yang selanjutnya dalam tulisan ini disebut dengan pelanggaran HAM) terjadi jika negara dan aparatusnya tidak atau gagal melaksanakan kewajiban menghormati, melindungi dan memenuhi Hak Asasi Manusia yang mengakibatkan pengurangan atau hilangnya penikmatan atas Hak Asasi Manusia itu sendiri. Pelanggaran HAM terjadi karena negara gagal memenuhi kewajibannya melindungi hak-hak (asasi manusia) yang dijamin dalam hukum internasional maupun nasional, ${ }^{1}$ baik karena pelanggaran karena tindakan (by commission) yang terjadi karena negara melakukan tindakan langsung untuk turut campur dalam mengatur hak-hak warga negara yang semestinya dihormati, dan pelanggaran karena pembiaran (by omission) yang terjadi karena negara tidak melakukan sesuatu tindakan atau gagal untuk mengambil tindakan lebih lanjut yang diperlukan untuk melaksanakan kewajiban hukum.

Perjuangan dalam menegakkan Hak Asasi Manusia di Indonesia dimulai sejak adanya penjajahan di Indonesia. Perjuangan ini tidak semata-mata hanya perlawanan mengusir penjajah, namun lebih jauh dari itu pada dasarnya juga merupakan perjuangan untuk menegakkan Hak Asasi Manusia (yang selanjutnya dalam tulisan ini disebut dengan HAM). Indonesia mengalami penjajahan berabad-abad yang dimana pada masa itu banyak sekali pelanggaran HAM seperti penculikan, kerja paksa, pembantaian, penyikasaan, penindasan, kesewenangwenangan yang merupakan fenomena umum yang terjadi pada saat itu. Tidak ada kebebasan, keadilan, perasaan aman, yang terjadi adalah ekploitasi besar-besaran terhadap manusia dan kekayaan alam Indonesia untuk kepentingan penjajah. ${ }^{2}$

1 Ari Yurino, 'Pelanggaran HAM, Korban, Dan Pemulihan' (Koleksi Pusat Dokumentasi ELSAM, 29 April 2019) <https://referensi.elsam.or.id/2019/04/pelanggaran-ham-korban-dan-pemulihan $>$ acessed 13 November 2019.

2 Sri Rahayu Wilujeng, 'Hak Asasi Manusia : Tinjauan dari aspek historis dan yuridis' (Fakultas Ilmu Budaya Universitas Diponogoro, 13 Juli 2013) < https://ejournal.undip.ac.id/index. php/humanika/article/view/5951> acessed 30 September 2019. 
Sejarah kelam bangsa Indonesia yang mencatat pelanggaran HAM hampir diseluruh wilayah Indonesia. Pelanggaran HAM di Indonesia sering terjadi dikarenakan adanya gesekan antara element masyarakat dengan lembaga pemerintahan atau antara lembaga pemerintah dengan lembaga pemerintah. Salah satu masyarakat di daerah yang merasa kurang puas terhadap kebijakan yang diterapkan didaerahnya adalah masyarakat di Provinsi Nanggroe Aceh Darussalam atau Aceh.

Pasca reformasi, transisi demokratik dari rezim otoritarianisme diperlukan adanya upaya pengungkapan kebenaran dan rekonsiliasi. ${ }^{3}$ Proses ini sangat penting dilakukan guna meminimalisir konflik sejarah yang dapat menjadi penghambat bangsa untuk masa depan. Bila permasalahan di masa lalu tidak segera dicarikan mekanisme penyelesaiannya, dikhawatirkan segregasi sosial di masyarakat akan terus berkepanjangan dan meruncing, yang sewaktu-waktu bisa menjadi sumber potensi konflik horisontal, kelak di kemudian hari. Mengingat begitu banyaknya dugaan kasus pelanggaran HAM di masa lalu, yang korbannya tidak sedikit, dan sampai saat ini belum terselesaikan. Melihat apa fakta yang ada, kendati masih minim dapat dikatakan bahwa negara sebenarnya telah memiliki iktikad baik dalam upaya pengungkapan kebenaran dan rekonsiliasi terkait dengan penyelesaian pelanggaran HAM di masa lalu, yang ditandai dengan lahirnya Undang-Undang Nomor 27 Tahun 2004 tentang Komisi Kebenaran dan Rekonsiliasi (dalam tulisan ini selanjutnya disebut dengan UU KKR). ${ }^{4}$

Pelanggaran HAM yang berat seperti yang terjadi pada masa konflik di Aceh, antara pemerintah Negara Republik Indonesia dengan GAM telah memakan banyak korban jiwa. Pemulihan hak-hak korban dan konsekuensi hukum untuk para pelaku kejahatan belum menemukan titik terang yang jelas, dikarenakan tidak adanya mekanisme untuk mencari kebenaran, lebih-lebih untuk mendapatkan keadilan.

\footnotetext{
${ }^{3}$ Lembaga Studi dan Advokasi Masyarakat (ELSAM), 'Mendorong Pembentukan Kembali Komisi Kebenaran dan Rekonsiliasi’ (Koleksi Pusat Dokumentasi ELSAM, 10 September 2011) $<$ https://advokasi.elsam.or.id/assets/2015/09/00000000_Polivy-Brief_Mendorong-pembentukan-kembali-UU-KKR.pdf $>$ accessed 30 September 2019.[2].

4 ibid.
} 
Namun pemerintah Aceh tidak berdiam diri mengenai kejahatan HAM dan ingin menuntaskan kasus-kasus pelanggaran HAM yang berat yang terjadi di Aceh melalu mekanisme Komisi Kebenaran dan Rekonsiliasi Aceh (yang selanjutnya dalam tulisan ini disebut dengan KKR Aceh) yang diterdapat pada Qanun sebagai produk hukum pemerintah Aceh.

\section{Komisi yang Berwenang Merumuskan dan Menentukan Upaya Rekonsiliasi dalam Menangani Kasus Pelanggaran Hak Asasi Manusia di Aceh}

Sekitar pada tahun 1998 setelah Rezim Orde Baru tumbang, gagasan pembentukan Komisi Kebenaran dan Rekonsiliasi adalah sebagai agenda dari Hak Asasi Manusia di Aceh. Gagasan tersebut disuarakan dan didorong oleh berbagai kalangan yakni tokoh politik, Lembaga Swadaya Masyarakat dan juga Komisi Nasional Hak Asasi Manusia (selanjutnya dalam tulisan ini disebut dengan Komnas HAM). Gagasan tersebut ditindak lanjuti dengan adanya kesepakatan antara Komnas HAM dengan pihak pemerintah Indonesia untuk membentuk Tim Informal Rekonsiliasi Nasional. Gagasan rekonsiliasi ini juga diupayakan sejumlah tokoh politik meskipun dengan format rekonsiliasi yang berbeda-beda yang diantaranya : "Rembuk Nasional; Forum Konsolidasi Nasional; sampai pada gagasan untuk membentuk Komisi Pencari Kebenaran dan Rekonsiliasi".5

Proses institusionalisasi pembentukan KKR diwujudkan pada tahun 2000 dengan mendorong masuknya agenda penyelesaian masa lalu dalam agenda reformasi nasional. Pembentukan KKR mendapatkan legalitas ketika Majelis Permusyawaratan Rakyat mengeluarkan ketetapan mengenai pembentukan Komisi Kebenaran dan Rekonsiliasi Nasional (dalam tulisan ini selanjutnya disebut dengan KKRN) tahun 2000. Ketetapan Majelis Permusyawaratan Rakyat ini menunjukan adanya kesadaran bersama sebagai bangsa, bahwa pada masa lalu telah terjadi penyalahgunaan kekuasaan dan pelanggaran HAM yang perlu diungkapkan demi menegakkan kebenaran. ${ }^{6}$

\footnotetext{
5 ibid.[4].

${ }^{6}$ ibid.
} 
Amanat pembentukan KKR dengan undang-undang khusus ini kemudian berlanjut dengan persiapan penyusunan naskah rancangan undang-undang oleh departemen hukum dan peraturan perundang-undangan sejak tahun 2000. Serangkaian pertemuan untuk menyusun naskah undang-undang tentang KKR dilakukan dengan masukan dari berbagai kalangan, termasuk Lembaga Swadaya Masyarakat (LSM). Terjadi beberapa kali perubahan rancangan undang-undang KKR sebelum akhirnya diserahkan oleh departemen hukum dan peraturan perundang-undangan ke Sekretariat Negara pada tahun 2003. ${ }^{7}$

Ditengah proses perumusan rancangan undang-undang KKR, Dewan Perwakilan Rakyat dan pemerintah Indonesia menjanjikan kepada rakyat Papua bahwa negara akan mempertanggungjawabkan berbagai bentuk pelanggaran HAM di Papua melalui dua instrumen yaitu, pengadilan HAM dan KKR. Janji itu dituangkan dalam UndangUndang Nomor 21 Tahun 2001 tentang Otonomi Khusus Papua. Komisi Kebenaran dan Rekonsiliasi dijanjikan oleh Dewan Perwakilan Rakyat dan pemerintah Indonesia sebagai jalan untuk menjaga keutuhan bangsa di Papua, yang saat itu terancam. ${ }^{8}$

Pembahasan rancangan undang-undang mengenai KKR mulai berjalan di Dewan Perwakilan Rakyat pada tahun 2003. Pembahasan ini dilakukan dengan membentuk panitia khusus yang terdiri dari 50 orang lintas fraksi. Tahun selanjutnya proses pembentukan KKR terasa sangat lambat. Sampai dengan tahun 2005, belum terbentuknya tim seleksi untuk memilih calon anggota KKR. ${ }^{9}$

Beranjak ke tahun 2006, di tengah keterlambatan pembentukan KKRN, pemerintah Indonesia menjanjikan kepada rakyat Aceh untuk membentuk KKR sebagai instrumen penyelesaian masalah HAM di Aceh. KKR yang dijanjikan untuk Aceh ini merupakan bagian dari KKRN. Janji untuk membentuk KKR tersebut juga merupakan hasil perundingan internasional antara pemerintah Republik Indonesia dengan GAM dalam sebuah Nota Kesepahaman/MoU Helsinki. ${ }^{10}$

\footnotetext{
7 ibid.

8 ibid.

9 ibid.

10 ibid.
} 
MoU Helsinki tidak tuduk hukum internasional (governed by international law) yang maksudnya didalamnya melekat elemen "intention to create obligation under international law" menurut Vienna Convention on the Law of Treaties adalah untuk membedakan antara perjanjian internasional yang diatur dengan hukum internasional (publik) dan perjanjian internasional yang meskipun para pihak adalah antarnegara tetapi diatur dengan hukum nasional salah satu pihak atau hukum negara lain yang disepakati oleh para pihak. MoU Helsinki tunduk pada hukum nasional Indonesia, "the government of the Acehnese people can be manifested through a fair and democratic process within the unitary state and constitution of the Republic of Indonesia". "Selain itu menurut Parthiana, "governed by international law" harus dibuktikan sejak perundingan, pembuatan naskah perjanjian, pemberlakuan, pelaksanaan, hingga penyelesaian sengketa, perjanjian internasional ini harus tunduk kepada hukum internasional. ${ }^{12}$

Saat perundingan MoU Helsinki, para pihak melakukan pendekatan informal terlebih dahulu yaitu melalui upaya yang dilakukan Juha Christensen sebagai mediator dengan GAM yang diwakili oleh Malik Mahmud dan Bachtiar Abdullah pada 30 Januari di rumah Juha hingga menuju pendekatan formal yang difasilitasi oleh suatu organisasi internasional sebagai pihak ketiga, CMI di Helsinki, Finlandia. Disebut sebagai pertemuan informal karena dua alasan yaitu pertama, Pemerintah Indonesia belum mengakui secara resmi keberadaan GAM sebagai sebuah negara (state), sifat informal tersebut merupakan strategi Pemerintah Indonesia untuk menghindari adanya negara dalamnegara dan menghindari dampak internasionalisasi terhadap kasus separatisme Aceh. Kedua, berkaitan dengan strategi yang diterapkan oleh CMI bahwa perundingan tidak mengikat kedua belah pihak hingga para pihak menyepakati agenda bersama sehingga tidak adanya kecemasan tentang hal yang dibicarakan pada saat perundingan akan mengikat para pihak. ${ }^{13}$

\footnotetext{
${ }^{11}$ Sefriani, Hukum Internasional Suatu Pengantar (PT Raja Grafindo Persada 2010).[179].

12 Wayan Parthiana, Perjanjian Internasional Bagian 1 (Mandar Maju 2002).[18].

${ }^{13}$ Moch. Nurhasim, Konflik dan Integrasi Politik Gerakan Aceh Merdeka; Kajian tentang Konsensus Normatif antara RI-GAM dalam Perundingan Helsinki (Pustaka Pelajar 2008).[118119].
} 
Khususnya dalam terbentuknya KKR Aceh sebagai rekomendasi dari MoU Helsinki kerap menimbulkan pertanyaan, apakah kerja pro-justitia Komnas HAM akan tereduksi atau bahkan ternegasikan dengan adanya penyelenggaraan Komisi Kebenaran dan Rekonsiliasi Aceh yang telah mendorong strategi pengungkapan kebenaran para korban. Hal ini menjadi pijakan penting dalam menegaskan hubungan antar lembaga negara yang ada dalam sistem hukum Indonesia.

Pembagian kekuasaan atau kewenangan negara kesatuan dapat diuraikan menjadi tiga hal. Pertama, kekuasaan atau kewenangan pada dasarnya diperoleh dari pemerintah pusat, sedangkan daerah diberikan hak dan kewajiban dari pemerintah pusat dengan cara dilimpahkan atau diserahkan. Jadi, terjadi proses penyerahan atau pelimpahan kewenangan. Kedua, pemerintah pusat dan pemerintah daerah tetap memiliki garis komando dan hubungan hierarkis. Pemerintah daerah sebagai subordinasi pemerintah pusat, namun hubungan yang dilakukan tidak untuk mengintervensi dan mendikte pemerintah daerah dalam berbagai hal. Ketiga, kewenangan atau kekuasaan yang dialihkan atau diserahkan kepada daerah dalam kondisi tertentu, dengan kondisi daerah tidak mampu menjalankan dengan baik, maka kewenangan yang dilimpahkan dan diserahkan tersebut dapat ditarik kembali ke pemerintah pusat sebagai pemilik kekuasaan atau kewenangan. ${ }^{14}$

Hal yang dimaksud kekhususan daerah adalah keistimewaan yang terdapat di masing-masing daerah, sedangkan yang dimaksud dengan keberagaman daerah adalah keberagaman antar daerah yang satu dengan yang lain masing-masing berbeda-beda. Hubungan antara pemerintah pusat dengan provinsi dan/atau kota atau kabupaten adalah subordinat dan dependent.$^{15}$ Pemberian otonomi seluasluasnya kepada daerah dilaksanakan menggunakan prinsip negara kesatuan. Karena seluas apapun otonomi yang diberikan kepada daerah, tanggung jawab

${ }^{14}$ Agussalim Andi Gadjong, Pemerintah Daerah, Kajian Politik dan Hukum (Ghalia Indonesia 2007).[71-72].

${ }^{15}$ Hanif Nurcholis, Teori dan praktik Pemerintah dan Otonomi Daerah (PT. Gramedia Widiasarana Indonesia 2005).[60]. 
akhir penyelenggaraan pemerintah daerah akan tetap ada di tangan pemerintah pusat. ${ }^{16}$

\section{Landasan Hukum Pembentukan Komisi Kebenaran dan Rekonsiliasi Aceh}

Upaya penuntasan pelanggaran HAM yang berat yang terjadi pada masa lalu di Indonesia melalui instrumen KKR mengalami hambatan dan tantangan yang tidak mudah. Hal itu dapat diihat dari ketidakseriusan pemerintah Indonesia dan Dewan Perwakilan Rakyat Republik Indonesia dalam menyelesaikan dasar hukum pembentukan KKR, mengingat Undang-Undang Nomor 27 Tahun 2004 tentang Komisi Kebenaran dan Rekonsiliasi telah dibatalkan secara keseluruhan oleh Mahkamah Konstitusi berdasarkan Putusan Mahkamah Konstitusi Nomor 6/PUU-IV/2006.

Konsep Komisi Kebenaran dan Rekonsiliasi di Aceh berdasarkan Pasal 229 Undang-Undang Nomor 11 Tahun 2006 tentang Pemerintahan Aceh (selanjutnya di dalam tulisan ini disebut dengan UU Pemerintahan Aceh) merupakan kebijakan hukum karena pembentukannya dengan undang-undang tersebut. Muatan KKR terdapat dalam 4 (empat) ayat yang menjelaskan:

1) Untuk mencari kebenaran dan rekonsiliasi dengan Undang-Undang ini dibentuk Komisi Kebenaran dan Rekonsiliasi di Aceh;

2) Komisi Kebenaran dan Rekonsiliasi di Aceh sebagaimana dimaksud pada ayat (1) merupakan bagian tidak terpisahkan dengan Komisi Kebenaran dan Rekonsiliasi;

3) Komisi Kebenaran dan Rekonsiliasi di Aceh berkerja berdasarkan 'peraturan perundang-undangan';

4) Dalam menyelesaikan kasus pelanggaran Hak Asasi Manusia di Aceh, Komisi Kebenaran dan Rekonsiliasi di Aceh dapat mempertimbangkan prinsip-prinsip adat yang hidup dalam masyarakat.

Pada ayat (1) nya mengatur mengenai: "untuk mencari kebenaran dan rekonsiliasi, dengan Undang-Undang ini dibentuk 'Komisi Kebenaran dan Rekonsiliasi di Aceh'.” Hal ini berarti, keberadaan dan kelembagaan KKR di Aceh berdasarkan undang-undang.

Pembentukan KKR di Aceh dengan UU Pemerintahan Aceh disebabkan Pasal 47

${ }^{16}$ Yusdianto, 'Hubungan Kewenagan Pusat dan Daerah Menurut Undang-Undang Nomor 23 Tahun 2014 tentang Pemerintah Daerah’ (2015) II Jurnal Ilmu Hukum Padjadjaran.[491]. 
ayat (2) UU Pengadilan HAM yang mengatur : "Komisi Kebenaran dan Rekonsiliasi harus dibentuk dengan undang-undang”. Hal ini berarti Komisi Kebenaran dan Rekonsiliasi Aceh (selanjutnya didalam tulisan ini disebut dengan KKR Aceh) secara kelembagaan merupakan lembaga yang dibentuk undang-undang.

Ketentuan Pasal 229 ayat (2) dan (3) UU Pemerintahan Aceh mengatur KKR Aceh merupakan bagian tidak terpisahkan dari KKR, serta bekerja berdasarkan UU KKR yang telah dibatalkan Mahkamah Konstitusi (selanjutnya dalam tulisan ini disebut dengan MK), MK berargumen bahwa pasal yang dibatalkan merupakan pasal jantung dari apa yang menjadi tujuan KKR. Dengan pembatalan pasal ini maka KKR tidak lagi bisa menjadi tujuannya, sehingga UU KKR perlu dibatalkan secara keseluruhan. ${ }^{17}$

Dalih bahwa Mahkamah Konstitusi tidak dapat menambahkan norma undangundang didalam putusannya (positive legislature), mungkin bisa menjadi alasan MK untuk sekedar membatalkan ketentuan-ketentuan dan materi-materi di dalam UU KKR tanpa berkewajiban untuk memperbaiki materi dari undang-undang yang diuji. Namun demikian, untuk tetap memastikan berlangsungnya proses pengungkapan kebenaran dan rekonsiliasi, dalam putusan MK merekomendasikan pembentukan aturan perundang-undangan mengenai KKR yang baru sesuai dengan UUD 1945, hukum humaniter dan hukum Hak Asasi Manusia internasional. ${ }^{18}$ Mahkamah Konstitusi memberikan jalan keluar dengan menyerahkan kepada kebijakan politik sepanjang KKR dibentuk bukan dengan Undang-Undang Nomor 27 Tahun 2004 tentang Komisi Kebenaran dan Rekonsiliasi yang telah dicabut. ${ }^{19}$

Perintah Konstitusional MK untuk membentuk kembali undang-undang tentang Komisi Kebenaran dan Rekonsiliasi yang sejalan dengan Undang-Undang Dasar Negara Republik Indonesia Tahun 1945 menjadi penting, karena penegasan ini memiliki arti bahwa MK mengakui urgensi dan konstitusionalitas KKR dalam penyelesaian pelanggaran HAM di masa lalu. Merujuk pada studi yang dilakukan

\footnotetext{
${ }^{17}$ Lembaga Studi dan Advokasi Masyarakat (ELSAM), Loc.Cit.

18 ibid.

19 Op.Cit.[5].
} 
Arjomand, yang mengatakan bahwa,

Pembentukan Mahkamah Konstitusi bagi negara yang mengalami proses transisi adalah dimaksudkan sebagai panduan dalam transisi demokrasi dan menjaga berjalannya konstitusi. Diungkapkan oleh Arjomand, 'in the new constitutionalism, just as the constitutional courts have assumed the function of guiding the transition to democracy' ${ }^{20}$

Oleh karena itu, pengingkaran terhadap amanat konstitusional putusan Mahkamah Konstitusi, dapat pula dimaknai sebagai pengingkaran terhadap konstitusi. Apalagi untuk negara yang tengah mengalami proses transisi. ${ }^{21}$

Pembentukan KKR juga menjadi mandat utama dari TAP MPR Nomor V/ MPR/2000 tentang Pemantapan Persatuan Nasional. Ketetapan tersebut menyatakan, untuk memantapkan persatuan dan kesatuan nasional harus diwujudkan dalam langkah-langkah nyata, berupa pembentukan KKR. Maksud dan tujuan ditetapkan TAP MPR tersebut dimaksud ialah : kesadaran dan komitmen yang sungguhsungguh untuk memantapkan persatuan dan kesatuan nasional harus diwujudkan dalam langkah-langkah nyata, berupa 'pembentukan Komisi Kebenaran dan Rekonsiliasi', serta merumuskan 'Etika Berbangsa dan Visi Indonesia Masa Depan'.

Pembentukan KKR ini sangat penting, serta dalam TAP MPR akan sangat berpengaruh pada penegakan supremasi hukum dan perundang-undangan, yang diterapkan secara konsisten dan bertanggungjawab, serta menjamin dan menghormati HAM.

Pembentukan KKR juga dimandatkan oleh Undang-Undang Nomor 26 Tahun 2000 tentang Pengadilan Hak Asasi Manusia, khususnya terkait dengan penyelesaian kasus pelanggaran HAM yang berat, yang terjadi sebelum diundangkannya undangundang ini. Pasal 47 Undang-Undang Nomor 26 Tahun 2000 tentang Pengadilan Hak Asasi Manusia menyebutkan sebagai berikut:

1) Pelanggaran Hak Asasi Manusia yang berat yang terjadi sebelum berlakunya

${ }^{20}$ Said Amir Arjomand, 'Political Reconstruction and Constitutional Politics' (2003) XVIII Journal International Sociology.[12].

${ }^{21}$ Op.Cit.[6]. 
undang-undang ini tidak menutup kemungkinan penyelesaiannya dilakukan oleh Komisi Kebenaran dan Rekonsiliasi.

2) Komisi Kebenaran dan Rekonsiliasi sebagaimana dimaksud dalam ayat (1) dibentuk dengan undang-undang. ${ }^{22}$

Komisi Kebenaran dan Rekonsiliasi di Aceh dibentuk dengan UndangUndang Nomor 11 Tahun 2006 memenuhi syarat MK tetap menjalankan tugas dan fungsinya karena dibentuk dengan kebijakan hukum melalui Undang-Undang Nomor 11 Tahun 2006 tentang Pemerintahan Aceh. Akan tetapi KKR Aceh tidak dapat lagi berkerja dengan mekanisme KKR berdasarkan Undang-Undang Nomor 27 tahun 2004 tentang Komisi Kebenaran dan Rekonsiliasi, tetapi bekerja dengan menggunakan kebijakan politik pemerintah melalui rehabilitasi dan amnesti sebagaimana pertimbangan Mahkamah Konstitusi. Oleh karena MK telah memberikan jalan keluar mekanisme kebijakan politik, kelembagaan KKR di Aceh perlu dirumuskan dengan peraturan presiden. Alasan rasional kelembagaan KKR di Aceh perlu dimuat dalam suatu peraturan presiden disebabkan:

1. Pembentukan Komisi Kebenaran dan Rekonsiliasi di Aceh adalah dengan undang-undang, berdasarkan Pasal 229 ayat (1) Undang-Undang Nomor 11 Tahun 2006 tentang Pemerintahan Aceh;

2. Pembentukan Komisi Kebenaran dan Rekonsiliasi di Aceh adalah kebijakan hukum negara melalui undang-undang, sebagaimana pertimbangan Mahkamah Konstitusi dan Pasal 47 ayat (2) Undang-Undang Nomor 26 Tahun 2000 tentang Pengadilan Hak Asasi Manusia;

3. Karena pembentukannya diatur dengan Undang-Undang Nomor 11 tahun 2006 tentang Pemerintahan Aceh, Komisi Kebenaran dan Rekonsiliasi di Aceh tidak terpengaruh secara hukum dengan dibatalkannya Undang-Undang Nomor 27 Tahun 2004 tentang Komisi Kebenaran dan Rekonsiliasi, tetapi kemudian harus didukung kebijakan politik untuk membuat Komisi Kebenaran dan Rekonsiliasi di Aceh dapat bekerja;

4. Kebiasaan administrasi pemerintahan, dalam hal pelaksanaan undang-undang terjadi hambatan, kendala dan masalah. Presiden merupakan penyelenggara pemerintahan tertinggi yang harus mengambil keputusan dan tindakan, sehingga dalam hal terjadi kendala dalam pelaksanaan kerja Komisi Kebenaran dan Rekonsiliasi di Aceh berdasarkan Undang-Undang Nomor 11 Tahun 2006 tentang Pemerintahan Aceh, dapat kembali dilaksanakan;

${ }^{22}$ UU Pengadilan HAM, Loc.Cit. 
5. Dengan mempertimbangkan persoalan kelembagaan adalah persoalan administrasi pemerintah, Presiden sebagai penyelenggara pemerintahan negara tertinggi dapat memutuskan skema pembentukan kelembagaan Komisi Kebenaran dan Rekonsiliasi di Aceh sebagai Satuan Kerja Khusus yang bersifat independen yang berada di lingkungan Sekretariat Bersama Rencana Aksi Nasional Hak Asasi Manusia, yang dibentuk berdasarkan Peraturan Presiden Nomor 75 Tahun 2015 sebagaimana diubah dengan Peraturan Presiden Nomor 33 Tahun $2018 .^{23}$

Dengan demikian, secara Normatif perlu ada perubahan kedua atas Peraturan

Presiden Nomor 75 Tahun 2015, yang selanjutnya dirubah dengan Peraturan

Presiden Nomor 33 Tahun 2008, dengan menambahkan 2 (dua) pasal, yaitu diantara

Pasal 5 dan 6, sebagai berikut usulan rumusannya :

\section{Pasal 5A}

1) Dalam Sekretariat Bersama RANHAM dibentuk Satuan Kerja Khusus yang mempunyai tugas dan fungsi mendukung penghormatan, perlindungan, pemenuhan, penegakan, dan pemajuan Hak Asasi Manusia melalui alternatif penyelesaian pelanggaran Hak Asasi Manusia dalam bentuk kebenaran dan rekonsiliasi.

2) Satuan Kerja Khusus sebagaimana dimaksud dalam ayat (1) menjalankan tugas dan fungsi komisi yang dibentuk undang-undang untuk mencari kebenaran dan rekonsiliasi dalam rangka proses pengungkapan kebenaran, pemberian restitusi, dan/atau rehabilitasi, serta memberikan pertimbangan amnesti.

3) Dalam melaksanakan tugas dan fungsinya, Satuan Kerja Khusus bersifat independen.

4) Susunan keanggotaan, tata cara pengangkatan dan pemberhentian, dan administrasi keuangan Satuan Kerja Khusus diatur dengan Peraturan Menteri yang menyelenggarakan pemerintahan di bidang Hukum dan HAM sebagai pimpinan Sekretariat Bersama RANHAM.

\section{Pasal 5B}

1) Pendanaan pelaksanaan Satuan Kerja Khusus bersumber pada :
a. Anggaran pendapatan dan belanja negara;
b. Anggaran pendapatan dan belanja daerah; dan
c. Hibah dalam dan/atau luar negeri.

2) Ketentuan lebih lanjut mengenai pengelolaan dan pertanggungjawaban pendanaan pelaksanaan Satuan Kerja Khusus diatur dengan Peraturan Menteri yang menyelenggarakan pemerintahan di bidang Hukum dan HAM sebagai pimpinan Sekretariat Bersama RANHAM setelah mendengarkan

${ }^{23}$ H.P. Wiratraman, et all. 2020., Op.Cit.[22-23] 
pertimbangan Menteri yang menyelenggarakan pemerintahan di bidang dalam negeri dan Menteri yang menyelenggarakan pemerintahan di bidang keuangan. ${ }^{24}$

Ketentuan demikian, menjadi relevan untuk menimbang produk hukum Peraturan Presiden sebagai jembatan dan sekaligus pondasi berkerjanya lembaga negara untuk bisa lebih memastikan Komisi Kebenaran dan Rekonsiliasi Aceh lebih optimal berkerja dan didukung oleh politik hukum pemerintahan nasional.

Landasan hukum pembentukan Komisi Kebenaran dan Rekonsiliasi Aceh terbentuk dari beberapa konflik, sejarah perjuangan rakyat Aceh, dan didorongnya oleh lembaga-lembaga negara serta para penggiat HAM di Indonesia. Dengan demikian landasan hukum KKR Aceh adalah melalui Undang-Undang Nomor 11 Tahun 2006 tentang Pemerintahan Aceh yang pada Pasal 229 ayat (1) menjelaskan: untuk mencari kebenaran dan rekonsiliasi, dengan Undang-Undang ini dibentuk Komisi Kebenaran dan Rekonsiliasi di Aceh. Hal ini merupakan mandat dalam UU Pemerintah Aceh tersebut, sekaligus juga merupakan kelanjutan dari MoU Helsinki, yang antara pemerintah Indonesia dengan GAM yang dalam bagian HAM yang menjadi klausula kesepakatan damai (pemerintah Indonesia-GAM), disebutkan bahwa KKR di Aceh akan dibentuk oleh KKR Indonesia, dengan tugas untuk memformulasikan dan menetapkan langkah-langkah rekonsiliasi.

\section{Komisi Kebenaran dan Rekonsiliasi di dalam Qanun Aceh}

Dalam bahasa Aceh istilah Qanun sudah digunakan sejak lama, dan diartikan sebagai aturan yang berasal dari hukum Islam yang telah menjadi adat. Salah satu naskah tersebut berjudul Qanun Syara Kerajaan Aceh (Teungku Di Mulek $1257 \mathrm{H}$ ), atas perintah Sultan Alauddin Mansur Syah yang wafat pada tahun 1870M. Naskah pendek ini (hanya beberapa halaman) berisi berbagai hal di bidang hukum tata negara, pembagian kekuasaan, berbagai badan peradilan dan kewenangan mengadili, fungsi kepolisian dan kejaksaan serta aturan protokoler dalam berbagai

24 ibid.[23-24]. 
upacara kenegaraan. ${ }^{25}$

Komisi Kebenaran dan Rekonsiliasi Aceh adalah lembaga independen yang dibentuk untuk mengungkapkan kebenaran, pola dan motif atas pelanggaran HAM dalam konflik bersenjata di Aceh, merekomendasikan tindak lanjut, merekomendasikan reparasi dan melakukan rekonsiliasi. Dimana dalam temuan KKR ditemukan adanya pelanggaran HAM yang dimana dalam menegakkan keadilan hukum akan menemukan kebenaran yang dimana disini adalah kebenaran atas temuan dari KKR atas suatu peristiwa pelanggaran HAM, baik mengenai korban, pelaku, tempat, maupun waktu. Dengan demikian KKR dalam Qanun Aceh merupakan produk hukum yang dihasilkan dari Undang-Undang Nomor 11 Tahun 2006 tentang Pemerintah Aceh yang kemudian menghasilkan peraturan daerah Aceh berupa Qanun Aceh Nomor 17 Tahun 2013 tentang Komisi Kebenaran dan Rekonsiliasi, yang dimana harus ditegakkan dan dijalankan sebagaimana mestinya dalam aturan tersebut.

\section{Tugas, Fungsi dan Wewenang Keberadaan Komisi Kebenaran dan Rekonsiliasi Aceh}

Perjanjian damai antara pemerintah Indonesia dan GAM dalam MoU Helsinki memandatkan mekanisme yudisial berupa pengadilan HAM dan mekanisme non yudisial berupa KKR di Aceh untuk menyelesaikan pelanggaran HAM di Aceh dimasa konflik dan dituangkan dalam Undang-Undang Nomor 11 Tahun 2006 tentang Pemerintah Aceh serta melahirkan Qanun Aceh Nomor 17 Tahun 2013 tentang Komisi Kebenaran dan Rekonsiliasi Aceh. Pembentukan pengadilan HAM dan KKR di Aceh merupakan kewajiban yang tidak terpisahkan dari tanggungjawab pemerintah, baik pemerintah Aceh maupun pemerintah pusat dalam menyelesaikan kasus pelanggaran HAM dan pemenuhan hak-hak korban adalah hak atas kebenaran, hak atas keadilan dan hak atas pemulihan kepada korban.

Beberapa prinsip-prinsip kerja Komisi Kebenaran dan Rekonsiliasi Aceh

${ }_{25}$ M. Hassan Mulyadi, Implementasi Perda Qanun Di Aceh Terhadap Anak Dibawah Umur Yang Melakukan Perjudian (Tesis Fakultas Hukum Universitas Airlangga 2017).[13-14]. 
meliputi: $:^{26}$

1. Proses pengungkapan kebenaran lokal dirancang dan diimplementasikan di Aceh, dengan tujuan utama untuk mengungkap kebenaran dan meluruskan sejarah Aceh;

2. Pembentukan sebuah komisi yang berdasarkan pada Undang-Undang Nomor 11 Tahun 2006 tentang Pemerintahan Aceh yang beroperasi melalui peraturan daerah Aceh. Dalam hal wewenangnya, komisi tidak akan menggunakan kekuasaannya di luar Aceh dan tidak memiliki kekuasaan untuk menghadirkan seseorang secara paksa;

3. Komisi memiliki mandat untuk memeriksa pelanggaran Hak Asasi Manusia yang dilakukan oleh semua pihak yang berkonflik, dengan perlindungan cukup untuk memastikan ketidakberpihakan dan kemandirian;

4. Mengimplementasikan mandat Komisi Kebenaran dan Rekonsiliasi pada level akar rumput;

5. Proses rekonsiliasi berbasis komunitas akan menyediakan mediasi konflik yang berhubungan dengan pelanggaran Hak Asasi Manusia pada masa lalu di level lokal; dan

6. Merupakan mekanisme non yudisial, sementara mekanisme yudisial mengacu pada Undang-Undang Nomor 26 Tahun 2000 tentang Pengadilan Hak Asasi Manusia.

Prinsip-prinsip kerja KKR Aceh merupakan proses yang dirancang dengan tujuan untuk mengungkapkan kebenaran berdasarkan UU Pemerintahan Aceh. Mandat untuk memeriksa pelanggaran HAM harus dijamin oleh komisi dengan mengedepankan, tidak ada pihak yang menunggani konflik yang ada dan secara mandiri. Jika implementasi mandat komisi sejauh pada bagian terdalam konflik yang ada dan didasarkan pada suatu komunitas yang menyediakan pada tataran lokal jika pengungkapan kebenarannya penelusurannya dilakukan pada masa lalu. Namun ada hal yang sangat ganjil dan sangatlah berlawanan dengan prinsip KKR Aceh, karena dalam hal untuk menghadirkan seseorang secara paksa tidak memiliki kekuasaan yang dalam catatan komisi, jika yang dihadirkan secara paksa sebagai upaya untuk mengungkapkan kebenaran mengenai konflik yang ada di Aceh, yang menyebabkan kekurangan dalam basis data komisi. Sementara untuk hal yang berwenang memutus perkara pelanggaran HAM adalah lembaga negara yang dalam hal ini adalah Pengadilan HAM sesuai dengan UU Pengadilan HAM.

\footnotetext{
${ }^{26}$ Indria Fernida, Satu Tahun Komisi Kebenaran dan Rekonsiliasi Aceh (KKRA): Pengungkapan Kebenaran atas Peristiwa Pelanggaran HAM di Aceh sebagai Upaya Memperkuat Perdamaian (Asia Justice for Rights (AJAR) \& KontraS 2017).[23].
} 
Adanya perbedaan wewenang disisi ini karena KKR berkerja sebagai lembaga nonyudisial sedangkan pengadilan HAM merupakan lembaga yudisial, ini yang harus dipertimbangkan lagi oleh pemerintah dan lembaga hukum di Indonesia.

Tugas dari KKR sendiri sangatlah banyak dan sudahmemenuhi standarpengungkapan kebenaran yang diantaranya, menyusun mekanisme; mengumpulkan informasi; melakukan penyelidikan; menerima pernyataan dan bukti lain; memberikan perlindungan; menjaga arsip-arsip; dan melaporkan temuan yang berkaitan dengan proses pengungkapan kebenaran dalam kasus pelanggaran HAM yang terjadi di Aceh; serta yang terakhir bertugas menyampaikan laporan akhir kepada pemerintah Aceh, Dewan Perwakilan Rakyat Aceh, pemerintah Indonesia, lembaga-lembaga penegakan HAM dan masyarakat.

Masyarakat sipil mengawal proses pembuatan Qanun hingga KKR berjalan hingga saat ini. Masyarakat sipil mengapresiasi komitmen para komisioner KKR Aceh untuk mendorong profesionalitas dan efektivitas KKR Aceh dalam berkerja. Satu tahun berjalannya KKR Aceh memperoleh beberapa catatan, antara lain: ${ }^{27}$

1. Komisi Kebenaran dan Rekonsiliasi Aceh mulai menempati kantor sekretariat sementara dan memiliki staf sekretariat sebanyak 12 orang. Komisi Kebenaran dan Rekonsiliasi Aceh juga mendapatkan dana sebesar 5 Miliar Rupiah untuk tahun 2017. Komisi Kebenaran dan Rekonsiliasi Aceh juga telah melakukan rekrutmen terhadap anggota kelompok kerja untuk membantu kerja ketujuh komisioner dengan masing-masing mandat.

2. Komisi Kebenaran dan Rekonsiliasi Aceh sudah mulai melaksanakan kegiatan sosialisasi tentang Komisi Kebenaran dan Rekonsiliasi di berbagai Kabupaten/ Kota di Aceh dan mendapatkan sambutan yang cukup baik dari masyarakat, tokoh-tokoh agama, dan pemerintah daerah.

3. Komisi Kebenaran dan Rekonsiliasi Aceh telah menyusun draf rencana strategis Komisi Kebenaran dan Rekonsiliasi Aceh dan program kerja. Komisi Kebenaran dan Rekonsiliasi Aceh memiliki beberapa aturan pendukung bagi mekanisme internal proses pengungkapan kebenaran.

4. Komisi Kebenaran dan Rekonsiliasi Aceh telah melakukan komunikasi dan koordinasi dengan beberapa institusi negara di tingkat nasional dan di Aceh sendiri. Komisi Kebenaran dan Rekonsiliasi Aceh telah membuat kerjasama institusional dengan Komisi Nasional Hak Asasi Manusia dan Komisi Nasional Perempuan dalam upaya mendukung kerja Komisi Kebenaran dan Rekonsiliasi Aceh. 


\section{Hubungan Komisi Kebenaran dan Rekonsiliasi dengan Pemerintah Indonesia dalam Mekanisme Perlindungan dan Pertanggungjawaban Negara yang Memberikan Kepastian Hukum atas Hak-Hak Korban Pelanggaran Hak Asasi Manusia yang Berat dalam Kasus Aceh}

Negara sebagai pemangku tanggungjawab (duty holder), yang harus memenuhi kewajiban dalam pelaksanaan HAM baik secara nasional maupun internasional, sedangkan individu dan kelompok-kelompok masyarakat adalah pemegang hak (right holder). Negara tidak memiliki hak karena negara hanya memikul kewajiban dan tanggungjawab (obligation and responsibility) untuk memenuhi hak warga negaranya, baik individu maupun kelompok yang dijamin dalam instrumen HAM Jika negara tidak mau atau tidak punya keinginan untuk memenuhi kewajiban dan tanggungjawabnya, pada saat itulah negara tersebut bisa dikatakan telah melakukan pelanggaran HAM atau hukum internasional. Jika pelanggaran tersebut tidak mau dipertanggungjawabkan oleh negara, maka tanggung jawab itu akan diambil oleh masyarakat internasional. Sedangkan negara dianggap melakukan pelanggaran HAM yang berat (gross vilence of human right), jika: ${ }^{28}$

1. Negara tidak berupaya melindungi atau justru meniadakan hak-hak warganya yang digolongkan sebagai 'non-derogable right'; atau

2. Negara yang bersangkutan membiarkan terjadinya atau justru melalui aparataparatnya tindakan kejahatan internasional 'international crimes' atau kejahatan serius 'seriouse crimes' yaitu kejahatan genosida, kejahatan terhadap kemanusiaan dan kejahatan perang, dan/atau negara tersebut gagal atau tidak mau menuntut pertanggungjawaban dari para aparat negara pelaku tindak kejahatan tersebut.

Upaya negara seharusnya untuk melindungi warga negaranya, bukan malahan menjadi pelaku utama pelanggaran HAM yang malah berbanding terbalik dalam upaya melindungi dan menjamin masyarakatnya dalam perlindungan HAM. Tidak

\footnotetext{
${ }^{28}$ Maidah Purwanti, 'Kewajiban dan tanggung jawab negara dalam pemenuhan Hak Asasi Manusia' (Kementerian Hukum dan HAM, 2016) < https://lsc.bphn.go.id/artikel?id=365> acessed 06 Desember 2019.
} 
berupaya atau meniadakan hak-hak warga negaranya merupakan non-derogable right, yang maksudnya : "Non-derogable right adalah 'Hak Asasi Manusia yang tidak dapat dikurangi dalam keadaan apapun". ${ }^{29}$

Selain negara, organisasi internasional seperti Perserikatan Bangsa-Bangsa, Komisi Eropa, ASEAN dan lain-lainnya, dikatakan sebagai aktor negara (stateactors). Hal ini dikarenakan organisasi internasional anggotanya adalah negaranegara, yang merupakan perkembangan dari hukum HAM internasional yang produknya mengeluarkan kebijakan-kebijakan yang dimana para anggotanya merupakan negara-negara anggota organisasi internasional harus membuat produk hukum HAM nasional atas perintah hukum HAM internasional yang sudah terikat sejak menjadi anggota dari organisasi internasional.

Meski di Indonesia yang sempat memiliki KKR namun sudah tidak ada lagi setelah tidak berlakunya atas pencabutan yang dilakukan oleh MK, di Provinsi Aceh telah memiliki komisi serupa yang dibentuk untuk mengungkapkan berbagai kasus-kasus pelanggaran HAM selama masa konflik Indonesia dengan GAM. Dengan demikian dapat memberikan kepastian hukum untuk memenuhi hak-hak korban pelanggaran HAM yang berat dalam kasus yang berada di Aceh.

Terdapatnya kegiatan khusus yang merupakan Rapat Dengar Kesaksian(RDK) yang dimana merupakan kegiatan yang khusus diadakan untuk mendengarkan kesaksian dari korban, saksi dan/atau pelaku pelanggaran HAM dan pelanggaran HAM berat. Para korban, saksi, pelaku, secara sukarela menyampaikan pikiran, perasaan, pengalaman atas suatu peristiwa pelanggaran HAM dan pelanggaran HAM berat di masa lalu di RDK. Rapat Dengar Kesaksian merupakan salah satu bagian dari proses pengungkapan kebenaran yang dilaksanakan KKR Aceh dalam rangka mengumpulkan informasi tentang pelanggaran HAM di Aceh pada masa lalu. Rapat Dengar Kesaksian menjadi ruang bagi saksi dan korban untuk menyampaikan pengalamannya secara sukarela tentang peristiwa yang dialaminya pada masa konflik di Aceh periode tahun 1976-2005.

${ }^{29}$ Diana Kusumasari, 'Hak Privasi' (Hukum Online, 2011) <https://www.hukumonline.com/ klinik/detail/ulasan/lt4d5605606b42e/hak-privasi/> accessed 30 April 2020. 
Landasan hukum KKR Aceh dalam pengungkapan kebenaran terkait dengan pelanggaran Hak Asasi Manusia (HAM) masa lalu di Aceh adalah Undang-Undang Nomor 11 tahun 2006 tentang Pemerintahan Aceh dan Qanun Aceh Nomor 17 tahun 2013 tentang KKR Aceh. Rapat Dengar Kesaksian pertama dilaksanakan KKR Aceh di Anjong Mon Mata, Banda Aceh pada 28 - 29 November 2018 yang menghadirkan empat belas pemberi kesaksian dari Aceh Besar, Pidie, Aceh Utara, Bener Meriah dan Aceh Selatan. Kegiatan RDK itu dibuka secara resmi oleh Gubernur Aceh yang diwakili Asisten I Sekretaris Daerah Aceh yang menyampaikan pesan Gubernur; "Pemerintah Aceh juga mengharapkan dengan berlangsungnya RDK dapat memberikan dampak positif dalam upaya pengungkapan kebenaran di Aceh, seperti mendorong para korban untuk berani tampil di ruang publik dalam menyampaikan kisahnya, dan merangsang kembali daya ingat terhadap kejadian masa lalu, dan untuk mendapatkan dukungan publik untuk upaya penggalian informasi tentang kebenaran masa lalu".

Pengungkapan Kebenaran adalah serangkaian tindakan KKR Aceh untuk mencari dan menemukan peristiwa pelanggaran HAM pada masa konflik di Aceh untuk tujuan rekonsiliasi korban dan pelaku yang meliputi pengumpulan informasi dan dokumen, investigasi, pengambilan pernyataan dan publikasi. Pemberi kesaksian adalah orang yang merupakan korban, saksi, pelaku pelanggaran HAM dan pelanggaran HAM berat yang secara sukarela memberikan kesaksiannya pada RDK atas peristiwa pelanggaran HAM dan pelanggaran HAM berat yang dialami, diketahui atau dilakukannya. ${ }^{30}$

Perjalanan KKR Aceh memang tidak mudah untuk mengusut tuntas kasus pelanggaran HAM yang berat yang terjadi di Aceh. Melalui Rapat Dengar Kesaksian dapat diperoleh data mengenai pelanggaran HAM yang berat yang terjadi di Aceh. Dalam pernyataan sikap Rapat Dengar Kesaksian KKR Aceh Tahun 2019 dapat dijelaskan dengan pernyataan yang dilakukan oleh Komisioner KKR Aceh sebagai berikut:

\footnotetext{
30 Zulfirman, 'Rapat Dengar Kesaksian',https://kkr.acehprov.go.id/rapat-dengar-kesaksian-rdk/, 08 Juli 2019, accessed 22 Juli 2020.
} 
Sepanjang tahun 2017 - hingga saat ini Komisi Kebenaran dan Rekonsiliasi (KKR) Aceh telah melakukan pengambilan pernyataan sebanyak 3040 saksi dan korban di 12 wilayah Kabupaten/kota di wilayah Aceh. Dari temuan tersebut, KKR Aceh mendapatkan informasi sebanyak 192 korban yang diduga masih dihilangkan paksa dalam kurun waktu 1990-2004.

Peristiwa Penghilangan Orang yang terjadi sepanjang konflik berlangsung telah mendapatkan perhatian yang serius dari masyarakat sipil baik di nasional maupun internasional. Karenanya penting bagi KKR Aceh untuk memperdengarkan kepada negara dan masyarakat melalui 20 (dua puluh) penyintas keluarga korban yang mewakili wilayah Aceh Besar, Pidie, Pidie Jaya, Bireuen, Aceh Utara-Lhokseumawe, Aceh Timur-Langsa, Aceh Tamiang, Bener Meriah, Aceh Tengah, Aceh Jaya, Aceh Barat dan Aceh Selatan yang keluarganya masih dihilangkan hingga kini yang berada di wilayah.

Para penyintas selama dua hari (19-20 November) akan menyampaikan kesaksiaannya sesuai dengan apa yang dialami keluarganya, dampak bagi keluarga saat terjadinya peristiwa hingga saat ini dan harapan keluarga kepada negara dan masyarakat. Setelah Para Penyintas menyampaikan kesaksian, KKR Aceh meminta pandangan dari ahli yang kompeten di bidangnya : Dr. Otto Nur Abdullah Ketua Komnas HAM periode 2012-2017 dan akademisi), Azriana R Manalu, S.H. (Ketua Komnas Perempuan), Ifdhal Kasim (Ketua Komnas HAM periode 2007 - 2012), Faisal Hadi (Jaringan Kerja Asia untuk Keadilan Transisi) dan Yulia Direzkia, M.Sc, (Psikolog).

Hasil dari RDK ini akan kembali disampaikan oleh KKR Aceh kepada publik melalui media pernyataan Akhir pada 20 November atau Rabu sebagai bentuk akuntabilitas kinerja KKR kepada publik. Kami mohon dukungan rekan-rekan media agar dapat berkontribusi untuk melakukan peliputan dengan mengedepankan aspek jurnalisme damai dan perlindungan bagi para pemberi kesaksian.

Banda Aceh, 18 November 2019

Komisioner KKR Aceh

(Afridal Darmi, Evi Narti Zein, Mastur Yahya, Muhammad Daud B, Fuadi Abdullah dan Ainal Mardiyah) ${ }^{31}$

Dari pernyataan Komisioner KKR Aceh dapat disimpulkan bahwa KKR Aceh sebagaimana mandat dan kewenangannya akan menyampaikan laporan yang komprehensif dari kegiatan RDK ini dan merekomendasikan kepada Pemerintah,

31 Ak, 'Pernyataan Sikap Rapat Dengar Kesaksian KKR Aceh Tahun 2019 'Penghilangan Orang : Kembalikan Mereka, Jangan Terulang”, https://kkr.acehprov.go.id/pernyataan-sikap-rapat-dengar-kesaksian-kkr-aceh-tahun-2019-penghilangan-orang-kembalikan-mereka-jangan-terulang/, 18 November 2019, acessed 22 Juli 2020. 
Pemerintah Aceh, Pemerintah Kabupaten/Kota dan DPR Aceh/DPRK, dengan beberapa hal sebagai berikut :

1. Rekomendasi berkenaan dengan pemenuhan hak-hak dasar korban;

2. Rekomendasi berkenaan dengan kewajiban Pemerintah dalam memulihkan hak-hak korban;

3. Rekomendasi berkenaan dengan masukan kebijakan khusus bagi Pemerintah;

4. Rekomendasi kepada Pemerintah dan DPR RI agar meratifikasi Konvensi Internasional tentang Perlindungan Semua Orang dari tindakan Penghilangan Orang Secara Paksa.

Banda Aceh, 20 November 2019

Komisioner KKR Aceh

(Afridal Darmi, Evi Narti Zein, Mastur Yahya, Ainal Mardiah, Fuadi Abdullah dan Muhammad Daud Berueh) $)^{32}$

Dari penjelasan diatas dapat dikatakan sejauh mana efektifitasya RDK yang dimana mengumpulkan data mengenai korban pelanggaran HAM yang berat yang terjadi di Aceh. Pengakuan terhadap RDK merupakan sumber utama juga dari KKR Aceh dalam mengajukan rekomendasi kepada Pemerintah, karena RDK merupakan kegiatan yang khusus yang dibentuk untuk proses pengungkapan kebenaran yang dilaksanakan KKR Aceh dalam rangka mengumpulkan informasi tentang pelanggaran HAM di Aceh pada masa lalu. Sementara kendala yang dialami oleh RDK bisa diatakan masalah pendanaan kegiatan khusus ini karena merupakan kegiatan yang ditujukan untuk mengumpulkan informasi dari para penyitas Hak Asasi Manusia.

\section{Praktek Impunitas yang Terjadi di Aceh}

Secara tekstual, impunitas dapat diartikan sebagai ketiadaan hukuman (the absence of punishment). Louis Joinet, seorang pelopor khusus PBB, menjelaskan bahwa impunitas mencakup semua upaya atau usaha dan praktik-praktik dimana pada satu sisi negara gagal menjalankan kewajibannya untuk menginvestigasi, mengadili

${ }^{32}$ Admin, 'Pernyataan Akhir Rapat Dengar Kesaksian Komisi Kebenaran dan Rekonsiliasi Aceh Penghilangan Orang', https://kkr.acehprov.go.id/pernyataan-akhir-rapat-dengar-kesaksian-komisi-kebenaran-dan-rekonsiliasi-aceh-penghilangan-orang/, 20 November 2019, acessed 22 Juli 2020. 
dan menghukum mereka yang bertanggungjawab atas pelanggaran Hak Asasi Manusia dan pada sisi lain, menghalangi korban dan keluarga korban menikmati hak mereka untuk mengetahui kebenaran dan pemulihan hak-hak mereka.

Dalam ruang lingkupnya, kata impunitas digunakan semata-mata untuk pelanggaran berat yang sifatnya massif dan sistematik (violations of a grave, systimatic and massive nature) terhadap hak-hak asasi manusia, dan seseorang yang dituduh melakukan kejahatan terhadap kemanusiaan lepas dari dakwaan, pengadilan atau penghukuman untuk tindakan kejahatan yang dilakukan dalam kapasitas jabatannya semasa rezim diktator berkuasa. ${ }^{33}$ Secara lebih jelas impunitas dapat didefinisikan sebagai :

"...the impossibility, de jure or de facto, of bringing the perpetrators of human rights violations to account - whether in criminal, civil, administrative or disciplinary proceedings - since they are not subject to any inquiry that might lead to their being accused, arrested, tried and if found guity, convicted, and to reparation being made to their victims ". ${ }^{34}$

ketidakmungkinan, de jure or de facto, membawa pelaku pelanggaran Hak Asasi Manusia untuk mempertanggungjawabkan perbuatannya - baik secara pidana, perdata, administratif, atau indisipliner - karena mereka, tidak pernah dijadikan subjek bagi pengusutan apapun yang memungkinkan mereka menjadi tertuduh, ditangkap, diadili, dan jika terbukti bersalah dihukum dan pemberian reparasi bagi para korbannya.

Kemudian, Impunitas juga didefinisikan sebagai :

“... a failure of State to meet their obligation to investigate violations, take appropriate meansures in respect of the perpetrators, particularly in the area of justice, to ensure that they are prosecuted, tried and duly punished, to provide the victims with effective remedies and reparation for suffered, and

${ }^{33}$ Charles Harper, Overcoming Impunity; Reconciliation in a Latin America Context. Charles harper adalah director WCC dari 1973-1992 Human Right Resources Office for Latin America, dari interim director dari WCC's Commission of the Churches on International Affairs 1992-95.of dual Brazilian/USA nationality, he edited the book entitled the book entitled Impunity : An Ethical Perspective. Six Case Studies from Latin America. WCC Publications, 1996.

${ }^{34}$ UN doc. E/CN.4/Sub.2/1997/20. Annex II. 'Set of Principles for the Protection and Promotion of Human Right through Action to Combat Impunity'. 
to take steps to prevent any to take steps to prevent any recurrenceof such violations". 35

Dari uraian tersebut dapat di definisikan, situasi eksepsional di Aceh dalam keadaan darurat tidak dapat dijadikan dasar argumen untuk mengabaikan proses eksaminasi atas kejahatan dan tanggungjawab lain untuk pemenuhan Hak Asasi Manusia. prinsip untuk merestruksi jurusdiksi pengadilan militer menjadi relevan untuk kembali di promosikan untuk mengakhiri siklus impunitas, sebagaimana dinyatakan dalam laporan Louis Joinet, Special Rapporteur on the question of the impunity of perpetrators of violations of human rights, sebagai berikut:

"In order to advoid military courts, in those countries where they have not yet been abolished, helping to perpetuate by virtue of a lack of independence resulting from the chain of command to which all or some of their members are subject, their jurisdiction must be limited solely to specifically military offences committed by military personnel...". ${ }^{36}$

"dalam rangka untuk menghindari peradilan militer, dalam negara-negara dimana jurisdiksi peradilan ini belum dihapus, membantu terjadinya kerusakan independensi yang dihasilkan dari rentang komando pada semua atau beberapa dari anggotanya yang menjadi subjek, jurisdiksi mereka harus dibatasi semata pelanggaran-pelanggaran militer yang spesifik yang dilakukan personil militer..."

Kekerasan dan pelanggaran HAM masih dan terus berlangsung dari waktu ke waktu dengan bentuk-bentuk kekerasan yang tidak berbeda dan berulang sehingga menjadi pola yang umum. Dengan pola kekerasan seperti ini maka kebijakankebijakan negara selama periode tersebut memiliki tujuan politik yang dijalankan secara teknis lewat bentuk operasi-operasi keamanan dan penggunaan sumber daya resmi negara lainnya, termasuk melalui pendirian berbagai pos-pos militer yang tersebar di berbagai wilayah. Keberadaan struktur pengamanan yang meluas seperti ini justru berlangsung seiring terjadinya berbagai bentuk kekerasan, seperti pembakaran rumah-rumah penduduk; penangkapan dan penahanan sewenangwenang; termasuk dengan penyiksaan terhadap orang-orang yang dituduh anggota

\footnotetext{
${ }^{35}$ ibid.

${ }^{36}$ Op.Cit, 'Set of Principles for the Protection and Promotion of Human Right through Action
} to Combat Impunity'. 
GAM maupun terhadap warga masyarakat lainnya yang dianggap sebagai bagian dari anggota keluarga atau mengetahui keberadaan GAM atau sekedar bertempat tinggal di wilayah yang dianggap lokasi persembunyian GAM. Sebagian dari mereka dibunuh tanpa proses hukum dan dihilangkan tanpa kejelasan nasib dan keberadaannya. ${ }^{37}$

Walaupun status DOM (Daerah Operasi Militer) itu sudah dicabut dan diikuti permintaan maaf beberapa Presiden yang sempat memimpin pemerintahan, termasuk petinggi keamanan pemerintah, ternyata tidak otomatis melepaskan masyarakat Aceh dari belenggu kekerasan. Pencabutan status ini juga tidak merubah eskalasi kekerasan yang terjadi di Aceh. Pelanggaran HAM yang berat menuai banyak kecaman dari berbagai macam kalangan, baik akademis maupun non akademis pun ikut turun dalam memperjuangkan HAM dalam tataran peradilan maupun non-peradilan. Perjuangan tersebut juga menuai banyak masalah yang diantaranya adalah penentuan pelaku kejahatan pelanggaran HAM yang berat. Sulitnya mengidentifikasi pelaku atas pelanggaran tersebut, dikarenakan adanya peranan negara yang melindungi pelaku-pelaku kejahatan HAM yang menjadikan sulit terungkapnya kasus-kasus pelanggaran HAM.

\section{Jaminan Pemenuhan Hak-Hak Korban atas Kasus Pelanggaran Hak Asasi Manusia yang Berat di Aceh}

Kasus kejahatan HAM di Aceh yang dipelopori oleh GAM merupakan pelanggaran HAM yang tidak luput dari jatuhnya korban jiwa adalah kegagalan dari pemerintah Indonesia dalam penegakkan HAM. Dalam hal menimbang dalam Qanun Aceh Nomor 17 Tahun 2013 tentang Komisi Kebenaran dan Rekonsiliasi pada huruf c menjelaskan bahwa, Pelanggaran Hak Asasi Manusia yang terjadi di Aceh harus ditelusuri kembali untuk keberlanjutan perdamaian di Aceh serta untuk kepentingan pemenuhan hak-hak korban atas kebenaran, keadilan dan hak untuk mendapatkan reparasi serta meluruskan sejarah demi pembelajaran bangsa

37 ibid. [8]. 
agar kejadian serupa tidak terulang lagi dimasa mendatang dan membentuk budaya menghargai Hak Asasi Manusia.

Komisi Kebenaran dan Rekonsiliasi Aceh memberikan reparasi kepada individu dan atau kelompok setelah proses pengungkapan kebenaran yang dimana reparasi bukanlah subtitusi dari kebenaran tetapi sebuah proses dan bentuk keadilan yang hanya bisa dilakukan setelah adanya kebenaran, dan karena itu pengakuan terhadap pengalaman korban. Namun, reparasi mendesak tetap dapat diberikan selama proses pencarian kebenaran berlangsung dengan melihat pada pertimbangan pentingnya pemulihan korban, baik fisik atau psikis yang dapat mengganggu proses pengungkapan kebenaran. Pertimbangan untuk reparasi mendesak ditentukan oleh KKR Aceh dengan mekanisme khusus.

Selanjutnya, Qanun ini menjelaskan bahwa reparasi merupakan kewajiban dan tanggung jawab pemerintah pusat dan/atau pemerintah Provinsi dan kabupaten/ kota Aceh. Dalam pelaksanaannya, reparasi untuk tujuan rehabilitasi korban dapat dilakukan kerjasama dengan organisasi yang memiliki kemampuan untuk memberikan upaya rehabilitasi yang dibutuhkan dengan memperhatikan hak-hak dasar korban, baik jangka pendek dalam bentuk pelayanan segera pada korban yang paling rentan, maupun jangka panjang dengan pengumpulan informasi untuk merancang program yang wajib dijalankan oleh pemerintah berdasarkan rekomendasi dari KKR Aceh.

Pemenuhan hak-hak korban dalam Qanun Aceh menjelaskan hak-hak yang dapat diperoleh oleh korban adalah reparasi, reparasi adalah hak korban atas perbaikan atau pemulihan yang wajib diberikan oleh negara kepada korban karena kerugian yang dialaminya, baik berupa restitusi, kompensasi, rehabilitasi, jaminan ketidakberulangan dan hak atas kepuasan. Dimana dalam penjelasan yang dimaksud dalam Qanun Aceh Nomor 17 Tahun 2013 tentang Komisi Kebenaran dan Rekonsiliasi Aceh adalah sebagai berikut:

a) Restitusi adalah ganti kerugian berupa materi atau ekonomi yang diberikan oleh pelaku atau pihak ketiga kepada korban atau keluarga korban yang merupakan ahli warisnya berupa pengembalian hak-hak korban yang telah dilanggar dan dirampas secara tidak sah. 
b) Kompensasi adalah ganti kerugian yang diberikan oleh negara kepada korban atau keluarga korban yang merupakan ahli warisnya atas kerugian ekonomi yang proporsional dengan pelanggaran yang dialami korban untuk memenuhi kebutuhan dasar, termasuk perawatan kesehatan fisik dan mental.

c) Rehabilitasi adalah pemulihan harkat dan martabat seseorang yang menyangkut kehormatan, nama baik, jabatan, termasuk pemulihan kondisi fisik, psikis, maupun status sosial, melalui pemberian layanan medis, psikologis, hukum, dan sosial pada korban sesuai kebutuhannya.

d) Hak atas kepuasan adalah untuk memuaskan korban yang termasuk di dalamnya dihentikannya pelanggaran, pengakuan kebenaran, pencarian orang hilang termasuk penggalian kuburan massal, deklarasi resmi atau putusan judisial yang memulihkan martabat korban, permintaan maaf resmi, sanksi terhadap pelaku, penghargaan korban melalui peringatan dan monumen. ${ }^{38}$

Adanya tujuan lain dari pengungkapan kebenaran, dimana proses pengungkapan kebenaran adalah serangkaian tindakan komisi untuk mencari dan menemukan peristiwa pelanggaran HAM yang tidak berat pada masa konflik di Aceh untuk tujuan rekonsiliasi korban dan pelaku yang meliputi pengumpulan informasi dan dokumen, investigasi, pengambilan pernyataan dan publikasi. Dalam melakukan tugasnya, komisi melakukan investigasi yang dimana adalah salah satu tindakan komisi dalam mengungkapkan kebenaran tentang tindak pelanggaran HAM yang tidak berat, yang dilakukan berdasarkan informasi dan data yang terkumpul untuk menemukan korban, pelaku, dan bentuk pelanggaran guna rekonsiliasi. Rekonsiliasi sendiri adalah hasil dari suatu proses pengungkapan kebenaran, pengakuan, dan pengampunan, dan penerimaan kembali korban dan pelaku oleh komunitas, melalui KKR Aceh dengan menggunakan mekanisme adat Aceh dalam rangka menyelesaikan pelanggaran HAM untuk terciptanya perdamaian dan persatuan bangsa.

Seluruh proses rekonsiliasi Aceh dicatat dalam suatu berita acara yang ditandatangani oleh korban, pelaku dan komisioner yang bertugas, serta lembaga adat yang hadir bertindak sebagai saksi. Dalam berita acara tersebut memuat identitas lengkap korban dan pelaku sebagai pendataan awal. Setelah itu adanya tanggal, tempat dan waktu pelaksanaan rekonsiliasi sebagai kepastian diberlangsungnya

${ }^{38}$ Qanun Aceh Nomor 17 Tahun 2013 tentang Komisi Kebenaran dan Rekonsiliasi Aceh, Ps. 1 ayat (22), (23), (24), dan (25). 
proses rekonsiliasi. Proses tersebut terdapat uraian lengkap mengenai pelanggaran HAM yang menjadi objek rekonsiliasi, dimana mencakup juga tanggal, tempat, waktu dan tindakan pelanggaran HAM yang dilakukan, serta kebijakan atau perintah yang diberikan sehingga mengakibatkan terjadinya pelanggaran HAM. setelah itu terdapat kesepakatan yang berupa bentuk, jumlah, waktu dan tata cara pembayaran restitusi atau sanksi adat. Satu hal yang tidak boleh tertinggal adalah terdapatnya uraian lengkap mengenai proses rekonsiliasi, karena itu merupakan hal penting dalam berjalannya rekonsiliasi, karena tanpa adanya data yang diuraikan dengan jelas maka proses itu menjadi sangat terhambat. Setelah semua materi muatan dalam proses rekonsiliasi disusun dan menjadi satu berkas, KKR membacakan kesalahan yang dilakukan oleh pelaku termasuk uraian tindakan yang mengakibatkan terjadinya pelanggaran Hak Asasi Manusia, sebelum berita acara tersebut dibumbuhi tanda tangan para pihak yang terlibat, baik korban, pelaku dan komisioner. Ketentuan mengenai tata cara dan teknis pelaksanaan rekonsiliasi mengacu pada adat Aceh yang diatur dalam Qanun Aceh Nomor 17 Tahun 2013 tentang Komisi Kebenaran dan Rekonsiliasi Aceh.

Reparasi merupakan jaminan yang memuat tentang pemenuhan hak korban dalam kasus pelanggaran Hak Asasi Manusia yang berat yang terjadi di Aceh, sebagai tujuan dari KKR Aceh yang merekomdasikan reparasi menyeluruh bagi korban pelanggaran HAM, sesuai dengan standar universal yang berkaitan dengan hak-hak korban.

Dalam melaksanakan tugas dan fungsinya, komisi dibantu oleh kelompok kerja di bidang reparasi yang menjadi bagian yang diatur di dalam Pasal 5 ayat (8) huruf c. Sementara tugas utama komisi adalah untuk menyusun mekanisme pengungkapan kebenaran, reparasi dan rekonsiliasi sesuai Pasal 8 huruf a. berlanjut ke Pasal 10 huruf 1 yang merupakan wewenang dari komisi, dimana harus merekomendasikan langkah-langkah reparasi yang adil bagi para korban. Dalam bagian penyusunan laporan sesuai dengan pasal 16 ayat (4) huruf c menjelaskan komisi dalam laporannya harus membuat rekomendasi demi perlindungan HAM untuk reparasi pada korban. Dalam ayat (5) menjelaskan rekomendasi sebagaimana 
dimaksud pada ayat (4) huruf b dan huruf c wajib dijalankan oleh pemerintah, pemerintah Aceh, dan pemerintah kabupaten/kota.

Mekanisme reparasi merupakan serangkaian tata cara mengenai bagaimana komisi melakukan tugasnya, apa yang harus dilakukan komisi kepada para korban dan pelaku pelanggaran HAM, dan pemerintah Aceh sebagai pemberi mandat kepada komisi dan penangung jawab atas berjalannya reparasi. Pelaksanaan reparasi harus dilakukan dengan pendekatan reparasi mendesak dan juga dapat dilakukan sebelum proses pengungkapan kebenaran selesai. Karena, rekomendasi yang diberikan komisi kepada pemerintah adalah sebagai bentuk yang harus di jalankan bukan hanya sebagai rekomendasi yang terhenti di tingkatan rekomendasi komisi, karena yang menjalankannya adalah pemerintah Aceh dan bentuk-bentuk reparasi yang harus diberikan oleh pemerintah berupa : restitusi, kompensasi, rehabilitasi, dan hak atas kepuasan, serta jaminan ketidakberulangan.

Keputusan Gubernur Nomor : 330/1209/2020 tentang Penetapan Penerima Reparasi Mendesak Pemulihan Hak Korban Pelanggaran HAM merupakan kabar baik kepada para korban dimana sudah didukungnya oleh gubernur selaku pemerintah daerah atas pemberian reparasi untuk para korban dengan berdasarkan pada ketentuan Pasal 26 ayat (2) Qanun Aceh Nomor 17 Tahun 2013 tentang Komisi Kebenaran dan Rekonsiliasi Aceh, yang dimana pemberian reparasi kepada individu dan/atau kelompok setelah proses pengungkapan kebenaran menjadi tanggung jawab Pemerintah/Pemerintah Aceh/Pemerintah Kabupaten/Kota. Keputusan Gubernur ini merupakan pertimbangan atas Pasal 26 ayat (2) Qanun Aceh Nomor 17 Tahun 2013 tentang Komisi Kebenaran dan Rekonsiliasi Aceh, yang dimana pemberian reparasi kepada individu dan/atau kelompok setelah proses pengungkapan kebenaran menjadi tanggung jawab Pemerintah/Pemerintah Aceh/Pemerintah Kabupaten/Kota dan Surat Ketua Komisi Rekonsiliasi Aceh Nomor 273/SK/KKR-Aceh/XII/2019 Perihal Rekomendasi Reparasi Mendesak Pemulihan Hak Korban.

Keputusan Gubernur tersebut memperhatikan Peraturan Komisi Kebenaran dan Rekonsiliasi Aceh Nomor 12/P-KKRA/V/2019 tentang Tatacara Baku Reparasi. keputusan tersebut menetapkan: 
KESATU :Menetapkan Penerima Reparasi Mendesak Pemulihan Hak Korban kepada Korban Pelanggaran Hak Asasi Manusia sebagaimana tercantum dalam Lampiran yang merupakan bagian tidak terpisahkan dari Keputusan Gubernur ini.

KEDUA : Pelaksanaan Reparasi Mendesak dilaksanakan oleh Badan Reintegrasi Aceh (BRA).

KETIGA : Keputusan Gubernur ini mulai berlaku pada tanggal ditetapkan. ${ }^{39}$

Keputusan tersebut ditetapkan pada tanggal 27 Mei 2020 di Banda Aceh, oleh Nova Iriansyah selaku Plt. Gubernur Aceh. Dengan demikian reparasi mendesak harus segera dilaksanakan kepada para korban pelanggaran HAM di Aceh, karena keputusan tersebut merupakan mandat dari Qanun Aceh Nomor 17 Tahun 2013 tentang Komisi Kebenaran dan Rekonsiliasi Aceh dan adanya keputusan tertutulis dari Pemerintah Aceh melalui Keputusan Gubernur tersebut.

\section{Kesimpulan}

Komisi Kebenaran dan Rekonsiliasi merupakan lembaga/institusi nasional dengan mekanisme non-yudisial yang dibentuk oleh Komisi Kebenaran dan Rekonsiliasi Nasional sebagai agenda HAM di Aceh sebagai dari amanat dari Nota Kesepahaman/Mou helsinki 2005 (RI-GAM), yang landasan pembentukannya atas Pasal 299 ayat (1)Undang-Undang Nomor 11 Tahun 2006 tentang PemerintahanAceh yang sebagai langkah untuk mencari kebenaran dan rekonsiliasi, yang setelahnya itu melahirkan Qanun Aceh Nomor 17 Tahun 2013 tentang Komisi Kebenaran dan Rekonsiliasi Aceh. Kedudukan hukum MoU Helsinki dalam peraturan perundangundangan itu tidak dapat di Subordinasi oleh aturan perundang-undang apapun, karena acuan politik hukum atas pembentukan KKR Aceh merupakan hasil dari perjanjian perdamaian yang harus segera dilaksanakan. Tugas, fungsi, dan wewenang KKR Aceh merupakan representatif dari Qanun Aceh Nomor 17 Tahun 2013 sebagai upaya untuk mengungkapkan kebenaran dan rekonsiliasi di Aceh.

Pemerintah sebagai pemangku kewajiban negara memiliki kewajiban bertanggung jawab melindungi, menegakkan dan memajukan HAM bagi masyarakat.

\footnotetext{
${ }^{39}$ Lihat Keputusan Gubernur Nomor : 330/1209/2020 tentang Penetapan Penerima Reparasi Mendesak Pemulihan Hak Korban Pelanggaran HAM.
} 
Penghapusan Undang-Undang 27 Tahun 2004 tentang Komisi Kebenaran dan Rekonsiliasi menjadikan kekosongan hukum nasional mengenai mekanisme yang mengatur tentang Komisi Kebenaran dan Rekonsiliasi. Agenda dari pemerintah dengan membentuk lembaga lain sebagai upaya untuk menuntaskan persoalan pelanggaran HAM dengan membentuk Dewan Kerukunan Nasional (DKN) banyak mendapat kritikan dari pegiat HAM di Indonesia. Dasarnya karena rencana tersebut melupakan poin penting tentang pengungkapan kebenaran dan rekonsiliasi sementara adanya lembaga non-yudiasial yaitu KKR. Aceh dengan KKR Acehnya sebenarnya mampu menuntaskan permasalahan HAM di Aceh, namun kendala yang masih di hadapi dalam permasalahan adanya ternegasikannya kerja KKR Aceh dengan Komnas HAM, dimana KKR Aceh berdasarkan UU Pemerintahan Aceh dan Qanun Aceh tentang KKR Aceh yang di mandatkan dari hasil MoU Helsinki, sedangkan Komnas HAM dilandasi dari UU Pengadilan HAM. Dalam mekanisme yudisial tidak adanya kelanjutan bagaimana pengadilan HAM di Aceh, sedangkan Komnas HAM tidak ada kekuatan lagi dalam mekanisme non-yudisial, karena UU KKR sudah di cabut oleh Mahkamah Konstitusi dan belum ada kembali peraturan yang berkaitan dengan Komisi Kebenaran dan Rekonsiliasi. Upaya pemenuhan hak-hak korban atas kasus pelanggaran Hak Asasi Manusia yang berat di Aceh atas dasar Qanun Aceh Nomor 17 Tahun 2013 tentang Komisi Kebenaran dan Rekonsiliasi yang dimana diberikannya kompensasi, restitusi, dan rehabilitasi serta adanya pemberian dana diyat yang dikelola oleh Badan Reintegrasi Aceh (BRA), serta diagendakan adanya Rapat Dengar Kesaksian (RDK) yang dimana dijadikan agenda khusus untuk melakukan proses rekonsiliasi.

\section{Daftar Bacaan}

\section{Buku}

Agussalim Andi Gadjong, Pemerintah Daerah, Kajian Politik dan Hukum (Ghalia Indonesia 2007).

Hanif Nurcholis, Teori dan praktik Pemerintah dan Otonomi Daerah (PT. Gramedia Widiasarana Indonesia 2005). 
M. Hassan Mulyadi, Implementasi Perda Qanun Di Aceh Terhadap Anak Dibawah Umur Yang Melakukan Perjudian (Tesis Fakultas Hukum Universitas Airlangga, 2017).

Moch. Nurhasim, Konflik dan Integrasi Politik Gerakan Aceh Merdeka; Kajian tentang Konsensus Normatif antara RI-GAM dalam Perundingan Helsinki (Pustaka Pelajar 2008).

Sefriani, Hukum Internasional Suatu Pengantar (PT Raja Grafindo Persada 2010).

Wayan Parthiana, Perjanjian Internasional Bagian 1 (Mandar Maju 2002).

\section{Jurnal}

Said Amir Arjomand, 'Political Reconstruction and Constitutional Politics' (2003) XVIII Journal International Sociology.

Yusdianto, 'Hubungan Kewenagan Pusat dan Daerah Menurut Undang-Undang Nomor 23 Tahun 2014 tentang Pemerintah Daerah' (2015) II Jurnal Ilmu Hukum Padjadjaran.

\section{Laman}

Ari Yurino, 'Pelanggaran HAM, Korban, Dan Pemulihan' (Koleksi Pusat Dokumentasi ELSAM, 29 April 2019) <https://referensi.elsam.or.id/2019/04/ pelanggaran-ham-korban-dan-pemulihan $>$

Diana Kusumasari, 'HakPrivasi'(Hukum Online, 2011)<https://www.hukumonline. com/klinik/detail/ulasan/lt4d5605606b42e/hak-privasi/>

Lembaga Studi dan Advokasi Masyarakat (ELSAM), 'Mendorong Pembentukan Kembali Komisi Kebenaran dan Rekonsiliasi' (Koleksi Pusat Dokumentasi ELSAM, 10 September 2011) <https://advokasi.elsam.or.id/ assets/2015/09/00000000_Polivy-Brief_Mendorong-pembentukan-kembaliUU-KKR.pdf $>$

Maidah Purwanti, 'Kewajiban dan tanggung jawab negara dalam pemenuhan Hak Asasi Manusia' (Kementerian Hukum dan HAM, 2016) <https://lsc.bphn. go.id/artikel?id=365>

Sri Rahayu Wilujeng, 'Hak Asasi Manusia : Tinjauan dari aspek historis dan yuridis' (Fakultas Ilmu Budaya Universitas Diponogoro, 13 Juli 2013) <https:// ejournal.undip.ac.id/index.php/humanika/article/view/5951> 


\section{Perundang-undangan}

Undang-Undang Dasar Negara Republik Indonesia Tahun 1945.

Undang-Undang Republik Indonesia Nomor 39 Tahun 1999 tentang Hak Asasi Manusia, Lembaran Negara Republik Indonesia Nomor 165 Tahun 1999, Tambahan Lembaran Negara Republik Indonesia Nomor 3886;

Undang-Undang Republik Indonesia Nomor 26 Tahun 2000 tentang Pengadilan Hak Asasi Manusia, Lembaran Negara Republik Indonesia Nomor 208 Tahun 2000, Tambahan Lembaran Negara Republik Indonesia Nomor 4026;

Undang-Undang Republik Indonesia Nomor 11 Tahun 2006 tentang Pemerintahan Aceh, Lembaran Negara Republik Indonesia Nomor 62 Tahun 2006, Tambahan Lembaran Negara Republik Indonesia Nomor 4633;

Qanun Aceh Nomor 17 Tahun 2013 tentang Komisi Kebenaran dan Rekonsiliasi, Lembaran Aceh Nomor 17 Tahun 2013, Tambahan Lembaran Aceh Nomor 60

Keputusan Gubernur Nomor : 330/1209/2020 tentang Penetapan Penerima Reparasi Mendesak Pemulihan Hak Korban Pelanggaran Hak Asasi Manusia. 